\title{
Proust et le livre à venir. Hommage à Philippe Chardin, sous la direction de L. Fraisse
}

\section{Ludovico Monaci}

\section{(2) OpenEdition}

10 Journals

\section{Édition électronique}

URL : https://journals.openedition.org/studifrancesi/21607

DOI : 10.4000/studifrancesi.21607

ISSN : 2427-5856

Éditeur

Rosenberg \& Sellier

\section{Édition imprimée}

Date de publication : 1 décembre 2019

Pagination : 601

ISSN : 0039-2944

\section{Référence électronique}

Ludovico Monaci, « Proust et le livre à venir. Hommage à Philippe Chardin, sous la direction de L.

Fraisse », Studi Francesi [En ligne], 189 (LXIII | III) | 2019, mis en ligne le 01 mars 2020, consulté le 11 novembre 2021. URL : http://journals.openedition.org/studifrancesi/21607; DOI : https://doi.org/ 10.4000/studifrancesi.21607

Ce document a été généré automatiquement le 11 novembre 2021.

\section{(c)}

Studi Francesi è distribuita con Licenza Creative Commons Attribuzione - Non commerciale - Non opere derivate 4.0 Internazionale. 


\title{
Proust et le livre à venir. Hommage à Philippe Chardin, sous la direction de L. Fraisse
}

\author{
Ludovico Monaci
}

\section{RÉFÉRENCE}

Proust et le livre à venir. Hommage à Philippe Chardin, sous la direction de L. Fraisse, Paris, Classiques Garnier, 2017, «Revue d'études proustiennes» 6, 531 pp.

1 Est-ce que «Longtemps» et «dans le Temps» resserrent circulairement la Recherche? Estce que cette dernière prépare le terrain à l'écriture du héros? Dédié à la mémoire de Philippe Chardin, le sixième numéro de la "Revue d'études proustiennes" essaie de donner des réponses à ces questions inéluctables.

2 La livraison se compose de vingt-trois contributions réparties en six volets. Les sections «Position du problème» (pp. 43-122) et «À l'orée du livre à venir» (pp. 123-168) soulignent comment le héros porte en germe son penchant artistique avant la révélation finale: la vocation, motif récurrent dans la littérature contemporaine de Proust, appelle en jeu, par analogie ou par contraste, l'idéalisme transcendantal de Schelling et le «Livre» mallarméen.

En tenant compte du risque de l'échec et des différentes acceptions du syntagme «temps perdu», les «Propositions structurelles» (pp. 169-230) convergent sur la valeur rédemptrice de l'écriture, tandis que «Les réponses des sciences humaines» (pp. 231-322) entament un dialogue avec d'autres disciplines. Les notions freudiennes d'übersehen et de nachträglich expliquent la maturation du livre rêvé, à mi-chemin entre construction philosophique et expérience sensible; la linguistique et la stylistique s'approchent des déictiques et des comparaisons pour essayer de trancher les nœuds gordiens narratoriaux et d'avancer des hypothèses sur le(s) livre(s) à venir. 
4 Les pôles participant à la création sont «L'auteur et le lecteur» (pp. 323-380): le prouvent les notes «pour le Livre» dans les brouillons du Temps retrouvé, la résurrection de François le Champi et l'invitation à la relecture du texte après le «renversement». Les projecteurs braqués sur Maurice Blanchot (auquel on emprunte le titre de la publication) et sur La préparation du roman de Roland Barthes, le répertoire «Livre à venir et livres futures» (pp. 381-518), fournit une panoramique sur le destin et sur le développement au $\mathrm{xx}^{\mathrm{e}}$ siècle de cette dimension tournée vers l'avenir.

5 Les voix de ce chœur de critique proustienne dirigé par Luc Fraisse se mettent au diapason: la solidité cohérente des argumentations et la structuration raisonnée des discours concourent à avancer des hypothèses plausibles et vérifiables sur l'énigme du livre à venir. 